\title{
As vítimas e suas marcas
}

Roberta Cristina de Oliveira Saçço ${ }^{1}$

RESUMO: Este artigo tem como objeto de estudo a obra literária de Bernardo Kuscinski, $K$. (2014) e depoimentos de sobreviventes da ditadura militar brasileira. Exploram-se, neste trabalho, a relação entre ficção e testemunhos orais. Em termos comparativos, nosso objetivo é mostrar como a literatura elabora imagens da violência contra o corpo e contra o psiquismo e como as vítimas elaboram os traumas dessa época.

Palavras-chave: Ficção; trauma; testemunho; ditadura militar.

RESUMEN: Esta investigación tiene como objeto de estudio la obra literaria de Bernardo Kuscinski, K. (2014) y los testimonios de los sobrevivientes de la dictadura militar brasileña. Ese trabajo se detiene mas en la relación entre la ficción y los testimonios orales. En términos comparativos, nuestro objetivo es mostrar cómo la literatura elabora imágenes de violencia contra el cuerpo y en contra de la psique y cómo las víctimas elaboran el trauma de esa época.

Palabras clave: Ficción; trauma; testimonio; dictadura militar.

Em situações de extrema violência, em que o sujeito é levado ao limite de suas capacidades físicas e psíquicas a experiência traumática impõe-se pela repetição. As vítimas não conseguem superar o horror sofrido porque a elaboração está além de suas defesas. Pretendemos discutir o conceito de trauma associado a situações de torturas físicas e psicológicas produzidas no Estado de guerra e de resistência política. A ditadura militar no Brasil produziu sua cota de doenças traumáticas que nos dias de hoje ainda trazem sérias

\footnotetext{
${ }^{1}$ Mestra em Estudos Literários pelo Programa de Pós-Graduação em Letras da Universidade Federal de Juiz de Fora, UFJF.
} 
consequências na memória tanto individual, daqueles que sofreram na pele a truculência do estado opressor, quanto na memória coletiva de toda nação. O reencontro com o passado é um mal necessário, segundo Kehl "Há eventos que não se consegue esquecer; outros não devem ser esquecidos" (KEHL, 2011, p.310). Lembrar como se produziu a injustiça é condição para transformar e reparar socialmente o mal produzido (KEHL, 2011, s/p). Em "Os crimes do Estado se repetem como farsa: artigo de Maria Rita Kehl sobre o trauma da ditadura", a autora completa:

\begin{abstract}
Se o reconhecimento dos fatos que um dia se tentou apagar não costuma trazer boas notícias, em contrapartida a supressão da verdade histórica produz sintomas sociais gravíssimos -a começar pela repetição patológica de erros e crimes passados. Melhor encarar as velhas más notícias e transformar a vivência bruta em experiência coletiva, no sentido proposto por Walter Benjamin. Para isso é preciso construir uma narrativa forte e bem fundamentada, capaz de transformar os restos traumáticos da vivência do período ditatorial em experiência coletiva. "Para que se (re)conheça, para que nunca mais aconteça (KEHL, 2013, s/p).
\end{abstract}

Quando Kehl afirma que "é preciso construir uma narrativa forte e bem fundamentada, capaz de transformar", ela reconhece o poder da narrativa na elaboração do trauma. O Brasil precisa dar voz às vítimas, silenciadas na transição democrática. O contato com as histórias de vida daqueles que ousaram lutar contra o sistema pode ser o que falta para a nação entender a cena política atual e não deixar que, mais uma vez, a história se repita. É urgente "encarar as velhas más notícias", nesse sentido as comissões da verdade são um importante mecanismo para que haja um verdadeiro revisionismo, tanto histórico quanto político no Brasil.

Nossas análises serão baseadas nos estudos de Maria Rita Kehl sobre o trauma. A autora, além de trabalhar como psicanalista, acompanhou durante o tempo em que participou da Comissão Nacional da Verdade ${ }^{2}$ relatos de vítimas ou parentes de desaparecidos políticos que através da narração dos momentos de dor buscaram contribuir para o processo de reescrita da história no Brasil. Com base em uma de suas obras, "O Ressentimento", e em dois artigos publicados por ela no site Boitempo, buscamos investigar como a literatura se associa à psicologia e traz para o campo simbólico o que representou o traumático na vida dos

\footnotetext{
2 Comissão Nacional da Verdade (CNV) é o nome da comissão que investigou as graves violações de direitos humanos cometidas entre 18 de setembro de 1946 e 05 de outubro de 1988 , por "agentes públicos, pessoas a seu serviço, com apoio ou no interesse do Estado".
} 
sujeitos envolvidos direta e indiretamente com torturas físicas e psicológicas, especificamente no caso brasileiro da ditadura militar.

Começaremos fazendo uso de alguns conceitos de trauma. O trauma "é aquilo que não se consegue esquecer, mas que, ao mesmo tempo, é intolerável recordar. Ou impossível de se transmitir" (KEHL, 2011, p.310). Encontramos também outra definição importante para o trauma no vocabulário de psicologia Laplache e Pontalis:

Acontecimento da vida do sujeito que se define pela sua intensidade, pela incapacidade em que se encontra o sujeito de reagir a ele de forma adequada, pelo transtorno e pelos efeitos patogênicos duradouros que provoca na organização psíquica (LAPLACHE E PONTALIS, 1991, P. 522).

O termo trauma inicialmente era utilizado pelas ciências médicas e está relacionado à ferida. A partir de Freud, a psicanálise se apropria do vocábulo e, no sentido psicanalítico, o trauma será definido como aquilo que está além, que excede as nossas capacidades psíquicas e não permite elaboração. De acordo com o relatório final produzido pela Comissão Nacional da Verdade, o trauma é o termo que designa as sequelas produzidas por um evento desorganizador das defesas psíquicas, cujas marcas se atualizam ao longo da vida e são transmitidas de forma inconsciente aos descendentes através da forma de se relacionar da vítima com o outro. Os impactos do traumático na vida do sujeito têm relação com a forma como ele reconstruiu suas relações com o mundo exterior, ou seja, suas relações de afeto com o sexo oposto e com familiares, enfim, o trauma se manifesta no relacionamento que a vítima se permite com o mundo (CNV, 2012).

Um trauma é mediado, necessariamente, pela maneira como cada vítima vivenciou e elaborou a experiência e pela forma como pôde reconstruir suas relações com o mundo exterior, a partir dos eventos marcados pelo sofrimento. $\mathrm{O}$ trauma representa uma forma de sofrimento continuado que, no limite, leva ao emudecimento (CNV, 2012, p.426/427).

Encontramos vários depoimentos no relatório da Comissão Nacional da Verdade em que os relatos mostram que as torturas deixaram marcas permanentes nas vítimas. Localizamos nas narrativas pessoas que ficaram cegas, surdas, estéreis, com danos cerebrais, paralisias, entre outros. Faremos uma análise dos danos físicos e psicológicos produzidos pela 
tortura, seja ela física ou psicológica. Para ilustrar o trauma dispomos de casos reais encontrados no relatório final da Comissão Nacional da Verdade, os quais serviram de inspiração para a ficção.

Anos se passaram e as vítimas e seus familiares ainda convivem com as avarias da repressão. Os danos psicológicos da tortura foram gravíssimos a ponto de haver relatos em que o suicídio foi a única saída encontrada. A ditadura militar no Brasil não poupou ninguém: crianças, mulheres grávidas e idosos; e o grau de violência dos relatos retrata um pouco do que foram os anos de chumbo.

Vejamos abaixo alguns fragmentos de depoimentos em que os sobreviventes descrevem as sequelas físicas que sofreram. Sabemos que toda sequela física vem acompanhada de sérias complicações psicológicas; no entanto, nossa intenção aqui é apresentar casos que dialogam com a teoria de Kehl e podem ter servido de matéria para ficção.

Não podemos falar de tortura sem mencionar o caso da presidenta Dilma Vana Rousseff, ex-militante da luta armada de esquerda, membro do Comando de Libertação Nacional (COLINA) e posteriormente da Vanguarda Armada Revolucionária Palmares (VAR Palmares). Foi presa e torturada, inclusive na cidade de Juiz de Fora, onde foi colocada no pau de arara, apanhou de palmatória e levou choques.

Dilma tem uma frase prototípica que resume bem o que representa o estigma da tortura na vida do sobrevivente: "As marcas da tortura sou eu. Fazem parte de mim" (CNV, 2014, 387).

\begin{abstract}
Uma das coisas que me aconteceu naquela época é que meu dente começou a cair e só foi derrubado posteriormente pela Oban. Minha arcada girou para outro lado, me causando problemas até hoje, problemas no osso do suporte do dente. Me deram um soco e o dente deslocou-se e apodreceu. Tomava de vez em quando Novalgina em gotas para passar a dor. Só mais tarde, quando voltei para São Paulo, o Albernaz completou o serviço com um soco arrancando o dente (CNV, 2014, p.386).
\end{abstract}

É nessa atmosfera de terror e agonia que Bernardo Kuscinski constrói sua narrativa. As imagens da violência, recorrentes na obra, vão ao encontro dos depoimentos prestados pelos sobreviventes ou pelos familiares dos desaparecidos à Comissão da Verdade da 
Assembleia Legislativa de São Paulo e com sua própria história de vida enquanto irmão de Ana Rosa, desaparecida política. Nesse sentido a narrativa dá voz a essas histórias silenciadas, como é o caso do ex-deputado federal, citado por Kuscinski, mas que não teve seu nome revelado na obra. Ao todo 173 deputados tiveram seus mandatos cassados nesse período, muitas histórias foram contadas e muitas outras ainda permanecem ocultadas, alguns até hoje não tem sua biografia conhecida. Em Juiz de Fora, por exemplo, o deputado estadual Clodesmidt Riani foi preso logo no início do golpe em 5 de abril de 1964, teve seu mandato cassado pela resolução $n^{\circ} 580$ da Assembleia Legislativa de Minas Gerais, e foi enquadrado na lei de Segurança Nacional como subversivo. Riani foi torturado, mas sobreviveu e contou à Comissão Municipal da Verdade de Juiz de Fora as violações a que foi submetido.

O caso nacional mais emblemático que se refere a parlamentares é o caso do deputado federal Rubens Beyrodt Paiva, sequestrado, torturado e morto nas dependências do DOICODI. Após intensas sessões de tortura o deputado não resistiu e veio a óbito, as torturas impetradas ao deputado foram relatadas pelo tenente-médico do Exército Amílcar Lobo em depoimento prestado à Comissão Nacional da Verdade.

\begin{abstract}
ao examinar o paciente verificou que o mesmo encontrava-se na condição de abdômen em tábua, o que em linguagem médica pode caracterizar uma hemorragia abdominal, sendo que naquela situação parecia ter havido uma ruptura hepática; que ao examinar o paciente este disse ao declarante chamar-se Rubens Paiva; que o declarante aconselhou a pessoa que o conduziu até aquela dependência que o paciente fosse imediatamente hospitalizado; que ao retornar para a sua jornada normal de trabalho, naquele batalhão, o declarante recebeu a notícia de que a pessoa a quem fizera atendimento de madrugada havia falecido (CNV, 2014, p.566).
\end{abstract}

No capítulo intitulado "A cadela", Kuscinki faz menção a um ex-deputado federal morto por envenenamento pelos militares. Como foi dito anteriormente, muitas histórias foram silenciadas, e a ficção se encarrega de quebrar as barreiras do silêncio, não importando aqui a identidade do ex-deputado, e sim a representação do momento histórico. Nesse capítulo, o narrador é um militar que trabalha para Fleury, e decide junto com o comparsa o que fazer com a cadela de Ana Rosa e Wilson capturada junto com o casal. A cadela havia sido usada como isca para a captura. Ana Rosa costumava passear com ela e num desses passeios os dois foram pegos, encapuzados e jogados num carro junto com a cadela. Por 
ordem de Fleury sumiram com o casal, mas ficaram com o animal que deveria ser poupado mesmo representando risco.

...quando eu falei em sacrificar a cadela, levei o maior esporro, me chamou de desumano, de covarde, que quem maltrata cachorro é covarde; quase falei para ele: e quem mata esses estudantes coitados, que tem pai e mãe, que já estão presos, e ainda esquarteja, some com os pedaços, não deixa nada, o que é? (KUSCINSKI, 2014, p. $65)$.

Embora a cadela fosse protegida pelo chefe não recebia o mesmo apreço dos subordinados, que pensavam em matá-la, assim como fizeram com o ex-deputado federal.

Mas nós ficamos aqui o tempo todo, com essa cadela nos atormentando, mas eu já sei o que vou fazer: dou mais dois dias, se ela não morrer sozinha, boto veneno na água, boto o veneno que demos àquele ex-deputado federal (KUSCINSKI, 2014, p. $65)$.

Mas não foram as sequelas físicas as únicas marcas deixadas pela tortura: as sequelas psicológicas acompanham as vítimas até os últimos dias de suas vidas. Algumas delas se põem a falar e dessa forma cooperam para que o sofrimento perca a força, e o trauma ganhe representação no campo simbólico. Em outras palavras, as narrativas são o único meio do sobrevivente enfrentar o passado traumático e elaborá-lo. Separamos alguns depoimentos em que o traumático submerge como sequela da tortura psicológica.

O primeiro caso é o de Jessie Jane Vieira de Sousa, que falou à CNV sobre o que representa ter sido presa. A liberdade conquistada não apaga as marcas produzidas pelos anos de reclusão, mesmo "livre" o sobrevivente convive com as marcas, apesar de querer livrar-se delas. Isso porque, pelas palavras de Jessie, parece que lhe faltam forças.

Eu sempre digo também que ter vivido muitos anos presa, de certa forma, tem o lado dramático, principalmente nove anos presa. É muito tempo, mas também é um tempo de aprendizagem e a... você tem também o tempo de assentar, de certa forma de apaziguar aquilo que havia sido vivido nos porões. Eu imagino... eu imagino não, eu sei, que os companheiros que saíam do DOI-CODI direto pra rua, muitos não suportaram. Nunca conseguiram sair do DOI-CODI. Evidente que nós nunca vamos conseguir sair do DOI-CODI. Mas saber que é preciso sair é importante (CNV, 2014, p.388). 
Mais uma vez as marcas parecem sufocar o sobrevivente porque é insuportável para a vítima que sua história seja ignorada. Mesmo "livre", do ponto de vista institucional, o sobrevivente estará para sempre preso às suas lembranças, pois de tempos em tempos as marcas o atormentam novamente fazendo com que se sinta para sempre preso a elas. Nas palavras de Kehl:

É insuportável, tanto para as vítimas quanto para seus herdeiros, que uma violência traumática permaneça não nomeada, insignificante para o resto do mundo. São casos em que o esquecimento fere como uma segunda violência, mais duradoura que a primeira (KEHL, 2011, p. 317).

No Brasil, as forças armadas cometeram, além dos crimes que já lhe são imputados, um crime ainda maior: calaram os sobreviventes, não permitindo que ajudassem a construir a história oficial da qual eles faziam parte. No final do regime, com a Lei da Anistia, os militantes foram soltos, mas carregavam as marcas do que foi um dos piores anos da história do país. Alguns foram mortos, outros até hoje estão “desaparecidos" e, na melhor das hipóteses, foram massantemente torturados. As marcas da repressão ainda estão coladas nos seus corpos e mentes porque sofreram, logo após a anistia, o momento de silêncio imposto. De acordo com Kehl

em "Os crimes do Estado se repetem como farsa: artigo de Maria Rita Kehl sobre o trauma da ditadura":

O modo como a ditadura negociou sua dissolução com a sociedade brasileira -uma negociação entre quem tinha as armas na mão e quem até então estivera sob a mira delas- funcionou como um verdadeiro convite ao esquecimento. $\mathrm{O}$ apagamento rápido (e forçado) dos crimes da ditadura lembra os efeitos perversos do esquecimento dos crimes da escravidão. (KEHL, 2013, s/p)

Após anos de torturas e graves violações dos direitos humanos, o problema foi "resolvido": anistia, ampla e irrestrita, assim foi perpetrado um dos maiores crimes contra nossa memória coletiva. O Brasil varreu dessa forma para baixo do tapete todas as sujeiras daqueles anos, e um Alzheimer nacional reinou soberano por décadas. 
Cristina Moraes de Almeida, uma das vítimas cujo testemunho foi recolhido pela Comissão Nacional da Verdade, não era militante nem tinha engajamento político, foi torturada por ser amiga de Carlos Eduardo Pires Fleury (Fleuryzinho) e de Alexandre Vannucchi, estes militantes. Cristina deu ênfase em sua memória à persistência dos acontecimentos marcantes vivenciados por ela e vive o drama de querer esquecer e não conseguir porque as memórias retornam sempre ao mesmo ponto e a torturam. É possível observar no depoimento de Cristina um ceticismo em relação à qualquer tipo de ajuda, ela não vê meios de se livrar da dor e considera frustrada qualquer tentativa de superação. Além disso, parafraseando Kehl, a impunidade também fere como uma segunda violência.

\begin{abstract}
Ainda está latente! Eu quero esquecer [...], mas eu te pergunto, qual é o profissional, na psicologia, que vai apagar essas marcas? Não tem! Não tem! E hoje em dia eles dizem: "Eu não sei, não vi, não me comprometa!". Olha, tacharam como torturador, é um elogio! Assassino em série, sem sombra de dúvida! Eu vou igual a uma desesperada. [...] É que tem muitos detalhes, está tudo vivo, eu queria ter tido uma amnésia [...] para eu sair e ir adiante, eu não consigo! [...] Está tudo vivo na minha memória [...], como se fosse ontem! (CNV, 2014, p. 389)
\end{abstract}

Essa persistência do evento traumático na memória foi representado em K. A personagem Jesuína, faxineira da Casa da Morte, assim como Cristina, não é capaz de se desvencilhar da memória do passado. Jesuína Gonzaga, vinte e dois anos, não consegue dormir, sofre alucinações e tem hemorragias todas às vezes em que a "chefia" altera a voz. Procura uma terapeuta a fim de se ausentar do trabalho. Fora orientada pelo chefe, ninguém menos que Sérgio Fleury, a procurar ajuda médica para fins de aposentadoria, no entanto, a terapeuta resolve conhecer melhor a história da paciente, mesmo sabendo que estaria se envolvendo em uma história perigosa.

Jesuína cumpria pena na penitenciária feminina de Taubaté por tráfico de drogas quando foi retirada da prisão pelo delegado Fleury, que lhe conseguiu uma pena condicional a fim de infiltrá-la na Casa da Morte em Petrópolis. No início, além de objeto sexual do delegado, trabalhava na copa e servia os presos. Havia sido admitida por Fleury, e deveria se passar por boazinha e coletar informações para ele.

Mas a cena que mais a chocou e que volta sempre à sua memória, tal como disse Cristina, "como se fosse ontem", foi a da garagem onde os corpos eram destroçados. 


\begin{abstract}
O Fleury já tinha voltado para São Paulo de madrugada. Eu sozinha tomando conta. Então desci até lá embaixo, fui ver. A garagem não tinha janela, e a porta estava trancada com chave e cadeado. Uma porta de madeira. Mas eu olhei por um buraco que eles tinham feito para passar a mangueira de água. Vi uns ganchos de pendurar carnes igual nos açougues, vi uma mesa grande e facas igual de açougueiro, serrotes, martelos. É com isso que tenho pesadelos, vejo esse buraco, pedaços de gente. Braços, pernas cortadas. Sangue, muito sangue (KUSCINSKI, 2014, p.132).
\end{abstract}

Diante da narrativa do traumático, Jesuína começa a soluçar, gemer e chorar e, logo é tomada por convulsões e escorrega da cadeira. Essa cena da ficção é sem dúvida a mais viva representação do real, pois muitos dos que sofreram não conseguem sequer falar sobre o trauma. Acreditam que na medida em que conseguirem se desvencilhar do passado, conseguirão esquecer o que lhe aconteceu, como se tudo fosse uma simples receita: esquecer para não sofrer. No entanto esse encontro com passado é um mal necessário: a um dado momento de sua vida a vítima precisa encarar seus fantasmas para enfim reconstruir sua vida.

A tortura psicológica a que eram submetidos os familiares das vítimas também é uma forma de violação dos direitos humanos, e produziu sua cota de distúrbios traumáticos, especialmente nos casos de desaparecimentos forçados em que a ausência do corpo se configura como uma aflição a mais. Esse é o caso de K., personagem central da ficção, no início, experimenta a impotência diante da recusa das autoridades de informar-lhe o paradeiro da filha, em seguida enfrenta a constatação de que ele estava diante de uma rede perversa liderada pelo próprio Estado. A falta de esclarecimento, as falsas informações, a impossibilidade de dar aos restos mortais o devido sepultamento, as estratégias de denegrir, tudo isso soma-se ao desconsolo dos familiares fazendo com que psicologicamente esses também sofram os efeitos da tortura.

Para os torturadores, não basta torturar, matar e desaparecer com os corpos, a repressão é cruel e torturar a família também é uma estratégia de guerra. K. sabia muito bem disso. A estratégia da repressão era confundir o inimigo, neste caso as famílias das vítimas: falsas notícias eram a todo tempo implantadas a fim de ludibriar e desestabilizar as buscas. Em um dos capítulos da narrativa, o autor reproduz o pronunciamento do ministro da justiça, Armando Falcão. O presidente revelaria o paradeiro dos desaparecidos, no entanto revela uma lista falsa. Sobre Ana Rosa houve apenas um comunicado rápido no final da transmissão. Não 
havia nenhum registro sobre ela e o marido nos órgãos do governo. Inicia-se então um novo tipo de tortura, a psicológica: "confundir o inimigo com mentiras é um recurso legítimo; equivalem as cortinas de fumaça da guerra convencional” (KUSCINSKI, 2014, p. 67).

A falsa lista seria apenas o começo da tortura psicológica a que eram submetidos os familiares, K. tanto importunou a repressão que se tornou alvo dos opressores. À medida que seus contatos começavam a incomodar o governo, a repressão respondia com requinte de crueldade. A estratégia era cansar o inimigo e uma expressão reiterada no texto mostra que muitas vezes eles conseguiam: "K. não se move, sente-se muito cansado" (KUSCINSKI, 2014, p. 68).

Após a divulgação da falsa lista, a repressão segue cruel, desumana e sem mostrar seu rosto. A guerra psicológica se revela uma tortura eficaz e todos os meios são usados para que os familiares de desaparecidos não se tornem mais um impecilho para a repressão. K. incomoda, faz uso de todos os recursos para encontrar a filha, e é levado a todo o momento a pistas falsas, no início o faziam acreditar que a filha estava viva e como o passar do tempo a busca pelo corpo foi a nova estratégia para confundir as famílias. "Procurar para salvar alguém que ainda pode estar vivo é uma coisa, mas procurar um corpo, só para poder enterrar é diferente" (KUSCINSKI, 2014, p. 75). A intenção era cansar as famílias até que eles desistissem de procurar por notícias e assim, dessem um tempo para a repressão. "Vamos quebrar a espinha desse velho. Vamos dar uma canseira nele, uma canseira de matar, até ele ter um infarto, filho da puta" (KUSCINSKI, 2014, p. 72).

A fim de tornar a vida dos familiares ainda mais difícil, os agentes do estado passaram a vê-los como ameaça e resolveram torturá-los. A tortura agora seria, portanto, psicológica. "O inimigo agora são as famílias desses terroristas. Mas temos que usar mais a cabeça, a psicologia" (KUSCINSKI, 2014, p. 73). Essas falsas pistas produziam nos envolvidos uma sobrecarga emocional muito grande e, mesmo sabendo que poderiam estar sendo enganados, a esperança de encontrar o parente desaparecido fazia com que fossem até as últimas consequências. E os torturadores sabiam disso: "Eles já sabem que é enganação, mas ainda querem se enganar. E nós ajudamos" (KUSCINSKI, 2014, p. 74-75).

Há no livro um capítulo que mostra a reação psicológica de K. diante desse tipo de tortura, pois mais uma vez, apesar do desespero da busca em vão, ele segue as pistas que o 
levariam ao corpo da filha, acendendo novamente a centelha da esperança: de acordo com um jornalista, presos políticos estariam enterrados em um ferro velho na baixada fluminense. Numa atitude impensada K. segue sozinho o encalço da filha, e ao chegar lá se convence de que deveria ter passado o informe à comissão de desaparecidos que mobilizaria os demais órgãos envolvidos. Conclui que isso ainda poderia fazer pois seria uma irresponsabilidade iniciar uma escavação sem a presença da perícia, da $\mathrm{OAB}$ e de testemunhas lavrando em ata.

Naquela noite, após um dia exaustivo, dormiu profundamente pela primeira vez desde o desaparecimento da filha. Teve um sonho perturbador que tentou desvendar e, como em todos os seus sonhos, cenas confusas se entrelaçavam. Diante de uma situação de extrema violência, a vítima tende a remoer a dor sofrida e as imagens do que causou o trauma persistem nos pensamentos por um bom tempo, podendo vir à tona através dos sonhos. Dessa forma, os sonhos são mensagens enviadas pelo inconsciente e podem levar a vítima a uma possível elaboração.

Voltando ao sonho de K., na primeira cena, ele cavava o solo com uma pá, isso porque ele deveria ter feito a escavação no dia anterior e não o fizera. Na próxima cena do sonho, K., já lá no fundo de suas escavações, volta seu olhar para cima e se depara com rostos encarando-o, eram rostos familiares, e de familiares de desaparecidos. Esta imagem do sonho deixa claro para ele que errara em não ter acionado todos os envolvidos, e ter partido sozinho atrás da pista do jornalista. De repente, se lembrou de outra cena do sonho: a pá bateu na pedra e detrás dela saiu uma cobra, e ele a matou de um golpe só. A cobra seria a imagem personificada da ditadura que precisava ser derrotada; e, embora não tenha sido picado por esta, sentiu calafrios como se estivesse doente. Nesse caso, ele, o pai não fora diretamente envolvido: não fora preso, torturado e morto. Mas sentia os arrepios como se fosse ele o principal envolvido. Era apenas um pai que sentia os calafrios do desaparecimento da filha, que sofria os golpes que nela foram executados, que procurava por notícias e que mesmo sem ter tido um fio de cabelo tocado estava sendo tão torturado quando ela.

Passados quarenta anos do fim da ditadura no Brasil, o sistema repressivo ainda continua articulado. A Ordem dos Advogados do Brasil inseriu, recentemente, na mídia uma emissão em que artistas de teatro dão voz a desaparecidos políticos. Ana Rosa Kuscinski foi uma das militantes que receberam essa homenagem. Após essa divulgação na mídia, o 
sobrinho, que nunca conhecera a tia, recebeu um telefonema de uma turista brasileira dizendo tê-la visto e com ela conversado num restaurante no Canadá. Assim, pistas falsas sempre surgem diante de algo novo, dessa vez a emissão produzida pela $\mathrm{OAB}$, trazendo novamente à tona a dor dos familiares.

É importante analisar a proposição do autor de que o sistema repressivo continua articulado. Assistimos, mesmo depois da entrega dos relatórios das comissões da verdade espalhados por todo país, a uma insistência das forças armadas em não assumir publicamente os crimes cometidos naquele período em que estiveram no poder. De acordo com Kehl (2011), não se pode dizer que a sociedade brasileira tenha perdoado os militares, nada foi perdoado porque nada foi levado até as últimas consequências, pois ao contrário do que fizeram os argentinos, nós não levamos os torturadores aos tribunais, não houve punição para os crimes praticados. Segunda a autora, "a sociedade brasileira costuma deixar barato o resgate das grandes injustiças de sua história para não manchar sua reputação de último povo feliz do planeta" (KEHL, 2011, p.326-327).

A ausência de um processo judicial que condenasse os autores dos crimes cometidos pelo Estado contribuiu, segundo KEHL (2011), para que, ainda hoje, parte da sociedade viva sob uma espécie de regime de exceção.

Nos dias atuais, honras militares são dadas a torturadores num desrespeito total à memória dos desaparecidos e àqueles que lutaram pela restauração da democracia. Recentemente, faleceu o general Leônidas Pires Gonçalves que chefiou o Estado-Maior do I Exército e o Comando de Operações de Defesa Interna (CODI) do I Exército, no Rio de Janeiro, entre março de 1974 e novembro de 1976. Nesse período, sob o comando deste general, o casal Wilson Silva e Ana Rosa Kucinski foi assassinados na "Casa da Morte” e teve seus corpos esquartejados e incinerados. Como chefe dos torturadores, o general Leônidas teria que responder por essa morte e por todas as outras ocorridas no período em que comandou o CODI do I Exército. No entanto, como recompensa pelos serviços prestados à Nação, em 1985, Leônidas tornou-se ministro do Exército de José Sarney, num governo democrático, e em seu funeral, recebeu honras militares do ministro da Defesa, Jacques Wagner, que afirmou em discurso: "Os soldados do seu Exército não consentirão que a 
retidão de seu caráter e a transcendência de sua alma sejam maculados por versões históricas capciosas" (POMAR, 2015, s/p).

"Versões históricas capciosas" seriam os relatórios finais das comissões da verdade espalhadas por todo o Brasil e principalmente ao Relatório Final da CNV que aponta o então general como um dos torturados da ditadura militar. É inadmissível que notícias como essa continuem a fazer parte dos noticiários sem que causem indignação na população. Concluo com Kehl citando Vladimir Safatle: "Nesse sentido, o único país que realizou de maneira bem-sucedida as palavras dos carrascos nazistas foi o Brasil: o país que realizou a profecia mais monstruosa e estúpida de todas. A profecia da violência sem traumas" (KEHL, 2011, p.324).

Definitivamente, pensar o trauma é também pensar a violência, esses casos apresentados são apenas uma pequena amostragem do que representa a violência para o aparelho psíquico humano. Uma frase da presidenta Dilma Vana Roussef resume bem tudo isso, "Acho que nenhum de nós consegue explicar a sequela: a gente sempre vai ser diferente" (CNV, 2014, p. 3).

A rapidez com que parte da população brasileira pareceu esquecer os crimes praticados pela ditadura militar criou no sobrevivente uma barreira para a superação do trauma. A lei de anistia funcionou como um apagamento da memória e, diante desse apagamento, as vítimas não puderam testemunhar os horrores sofridos. E assim, a história contada pelos militares ganhou eco na sociedade. Segundo KEHL (2011), é fundamental a importância do outro na reconstrução da memória traumática, bem como na superação do trauma.

Foram necessárias mais de três décadas para que as vítimas encontrassem na própria sociedade a testemunha necessária para que pudessem iniciar o processo de elaboração do trauma, pois a testemunha não é aquele que participou da cena traumática, mas sim aquele que é capaz de ouvir a sua narração até o fim. Através do testemunho a vítima torna pública a experiência do horror a que foi submetida e, de acordo com Kehl, os testemunhos das vítimas "impedem que a chaga, fechada no silêncio e no esquecimento, infeccione, contaminando o futuro para sempre" (KEHL, 2011, p. 312).

O trabalho com a memória é necessário e urgente, "é o trabalho da memória que 
permite o verdadeiro esquecimento, os desligamentos das cargas libidinais fixadas às representações da cena traumática" (KEHL, 2011, p.311). É através do testemunho que o sobrevivente consegue elaborar a representação simbólica do horror sofrido; e, de acordo com KEHL (2011), o processo de simbolização não pode ser individual; ele é coletivo e acontece, por exemplo, na figura do analista, ou de comunidades que criam formas para relembrar as atrocidades sofridas, como fizeram os parentes dos desaparecidos políticos no Brasil na década de 80. "Não se trata de retornar sempre ao mesmo ponto nem de repetir o ocorrido, e sim de inscrever no campo simbólico, no campo das representações coletivas, as marcas do vivido" (KEHL, 2011, p.317).

Isso acontece porque é insuportável para as vítimas e para seus familiares que a violência permaneça insignificante para o resto do mundo, "são casos em que o esquecimento fere como uma segunda violência, mais duradoura que a primeira" (KEHL, 2011, p.317). Precisamos com urgência inscrever essas mortes, que se mantiveram anônimas por mais de quatro décadas, na memória coletiva do país, e uma das formas de se fazer isso é inserindo a verdadeira história da ditadura militar nos currículos escolares.

KEHL (2011) analisa o ressentimento no Brasil. Segundo ela é preciso diferenciar o conformismo ressentido dos movimentos de reivindicação e luta populares, do ressentimento propriamente dito. O ressentimento seria a impossibilidade do sujeito de esquecer ou superar um agravo, "o que ocorre no ressentimento é que o ofendido não se atreve, ou não se permite, responder a altura da ofensa recebida" (KEHL, 2011, p.15). Não é objetivo desse trabalho discutir a teoria do ressentimento, o que nos propomos a discutir é o que Kehl chama de conformismo ressentido, experimentado pelas as vítimas da ditadura militar porque não puderam reagir às ofensas recebidas, já que qualquer reação custaria a própria vida. "O ressentimento não se confunde com a revolta silenciada nem com a resignação forçada que se produz sob regimes totalitários ou em sociedades fortemente estratificadas" (KEHL, 2011, p.21). Não faz sentido pensar em ressentimento nos casos em que o agressor é um Estado de exceção, soberano, que exerce poder sobre a vida e a morte das vítimas. É preciso haver condição de igualdade entre opressor e oprimido para que haja ressentimento. Sendo assim, como reagir a uma injustiça sob uma ditadura militar?

De acordo com KEHL (2011), alguns prisioneiros escolhem a morte como meio de 
preservar sua humanidade. E a ditadura brasileira, lamentavelmente, coleciona vários casos que ilustram essa afirmação: "Morrer, ou deixar-se matar, é a afirmação extrema de insubmissão sob regimes totalitários" (KEHL, 2011, p.20). A ficção aqui estudada também representa essa situação: Ana Rosa e Wilson firmaram um juramento de não se deixarem pegar vivos, para não entregarem companheiros sob tortura. Com objetivo de se matarem, caso fossem pegos, andavam com uma cápsula de cianureto num vão entre os dentes que usariam em caso de emergência. Sobre a morte de Ana Rosa, a faxineira da Casa da Morte, onde ela teria sido morta, narra:

O Fleury mandou eu descer e ficar de novo com a moça, para ver se ela falava mais alguma coisa. De madrugada chegou o doutor Leonardo. Lá de baixo eu adivinhei que era o médico e avisei baixinho, quando vem o médico é porque vão maltratar, fazer coisa ruim. Logo depois vieram buscar ela. Foi aí que ela de repente meteu um dedo na boca e fez assim como quem mastiga forte e daí a alguns segundos começou a se contorcer. Eles nem tinham aberto a cela, ela caiu de lado gemendo, o rosto horrível de se ver e logo depois estava morta. Parecia morta e estava morta mesmo (KUSCINSKI, 2014, p. 130).

Voltemos aos casos analisados pela Comissão Nacional da Verdade que ilustram a teoria do conformismo ressentido que aqui discutimos. A morte é ao mesmo tempo uma forma de resistência e uma consequência do cessar de resistir já que as consequências da tortura também tentem a atingir a personalidade da vítima levando-a ao suicídio. Esse foi o caso, por exemplo, de frei Tito de Alencar Lima, religioso e militante da $\mathrm{ALN}^{3}$. Frei Tito foi preso acusado de participar da organização do congresso da $\mathrm{UNE}^{4}$ em Ibiúna (SP) e por manter relações com Carlos Marighella, um dos principais organizadores da luta contra a ditadura militar no Brasil. O fato que é que Frei Tito foi submetido a 40 dias de torturas pela equipe do delegado Sérgio Paranhos Fleury, conhecido pela truculência e pelo ódio a padres que se envolviam em política. Em um dos interrogatórios, ouviu de um torturador: "Se não falar será quebrado por dentro, pois sabemos fazer as coisas sem deixar marcas visíveis. Se sobreviver jamais esquecerá o preço de sua valentia" (CNV, 2014, p. 485). No fím do

\footnotetext{
${ }^{3}$ A Ação Libertadora Nacional (ALN) era uma organização revolucionária brasileira dissidente do partido comunista brasileiro que se lançou contra o regime militar em fins da década de 1960. Seu principal líder Carlos Marighela fundou a organização em 1967 após romper com o partido comunista brasileiro (PCB), pois este se opunha a luta armada. (CMV, 2015, p.246)

${ }^{4}$ A União Nacional dos Estudantes (UNE) é a principal entidade estudantil brasileira.
} 
interrogatório, Frei Tito tentou suicidar-se com uma lâmina de barbear, mas foi impedido para que a tortura continuasse. Depois disso, foi incluído na lista de prisioneiros que deveriam ser soltos em troca do embaixador suíço sequestrado pela $\mathrm{VPR}^{5}$ e passou a viver em comunidades dominicanas no Chile, na Itália e na França e, mesmo tendo buscado tratamento psiquiátrico, suicidou-se quatro anos mais tarde, aos 28 anos.

Em um dos capítulos de sua obra, Kuscinki dá voz a uma amante do delegado Sérgio Paranhos Fleury. Esta comenta com uma mãe, que a procura em busca de informações sobre o filho, a respeito do ódio que o amante nutria por padres que se envolviam em política, e faz uma alusão ao caso do Frei Tito. "Eu sei desse caso do padre que se matou por causa dele, não sei tudo, mas o que sei já me deixa mal" (KUSCINSKI, 2014, p. 106). Para Fleury padre que se envolvia com política não era padre e sim terrorista. Leonora, a amante, suspeita de que ele tenha sofrido algum tipo de violência sexual na infância, quando fora coroinha, suspeita esta fundamentada no ódio que ele nutria por padres. Ela cita ainda a prisão dos padres dominicanos, e fala da reação de Fleury no dia em que foram detidos.

\begin{abstract}
No dia em que prenderam os dominicanos ele festejou. Parece que fecharam um restaurante na Lapa só para eles; a equipe toda foi comer e encher a cara. Nunca tinha visto ele tão alegre, como se tivesse se livrado de um peso. Fiquei sabendo dessa farra porque eles combinaram pelo telefone e escutei. Aquela noite ele chegou tarde e me pegou como um touro. Foi a única vez desse tempo todo que voltou aquele medo do primeiro dia. Foi uma noite difícil. Tive palpitação, sabe? Uma hora eu pensei que eu é que estava sendo torturada, esganada, não o padre (KUSCINSKI, 2014, p.107).
\end{abstract}

Frei Tito não podia se defender, não estava em igualdade de condições com o opressor. Depois de livre, embora tenha sido submetido a tratamentos psicológicos, não foi capaz de conviver com as marcas do trauma e continuar vivo. O trauma não foi elaborado e o suicídio foi a única forma encontrada para se livrar do sofrimento.

\footnotetext{
5 A Vanguarda Popular Revolucionária (VPR) foi uma organização de luta armada brasileira de extrema esquerda que lutou contra o regime militar de 1964, visando à instauração de um governo de cunho socialista no país. Formou-se em 1966 a partir da união dos dissidentes da organização Política Operária (POLOP) com militares remanescentes do Movimento Nacionalista Revolucionário (MNR). (CMV, 2015, p.250)
} 
Mesmo estando na França, frei Tito alegava estar sendo perseguido por Fleury, que estaria ameaçando a sua família. Após vários acompanhamentos psiquiátricos, frei Tito se enforcou numa zona rural na França. Entre suas anotações nos últimos meses de vida havia a seguinte frase: "é melhor morrer do que perder a vida (CNV, 2014, p. 390).

Outro caso que merece destaque em nossa análise é o do militante Carlos Eduardo Pires Fleury, morto pela ditadura militar em 1971. Este contou sobre sua tentativa de suicídio em uma carta endereçada ao então chefe de gabinete do ministro da Justiça, doutor Manoel Gonçalves Ferreira Filho. A tortura levou Carlos atentar contra sua própria vida, cravando uma tesoura em seu peito:

\begin{abstract}
Não vou enumerar exatamente o que sofri momento a momento que lá estive, vou dar alguns exemplos dos "métodos" de interrogatórios que sofri: o pau de arara, telefone, choques na cabeça, nos órgãos sexuais e no resto do corpo todo como o mostram as cicatrizes que tenho até hoje. Os choques que levei no segundo dia de tortura foram de 220 volts e durante mais de cinco horas seguidas pendurado no pau de arara, o que me causou uma parada cardíaca. Quando isto ocorreu estavam chegando, naquele momento, na O.B., os delegados do DOPS, senhores Tucunduva, Fleury e Raul Ferreira. Foram estas pessoas que me fizeram voltar à vida, através de massagem no coração, fricção com álcool pelo corpo etc., pois o pessoal da O.B. deu-me como clinicamente morto. Esta sessão de cinco horas de 220 volts foi precedida por uma tarde inteira de agressões e choques na cadeira do dragão, além de ter ficado na noite anterior das $22 \mathrm{~h} 30$ até $6 \mathrm{~h} 30$ da manhã deste dia no pau de arara, levando choques. Quando tive a parada cardíaca, o comentário lá era que mais um havia morrido e o major Waldir comentava "que a tortura devia ser menos violenta para não matar e obrigar o cara a falar" [...] Após a noite em que quase perdi a vida fui violentamente ameaçado de que me torturariam meses a fio caso não falasse o que os meus carrascos pretendiam. E como percebi que isto era verdade [...] levei-os a um ponto de uma rua em que pretendia jogar-me embaixo de um ônibus [...] abreviando a história, consegui uma tesoura numa butique [...] e enfiei esta tesoura no peito, por felicidade ou infelicidade, ainda não sei à esta altura, a lâmina penetrou um pouco acima do coração [...] Por incrível que pareça mesmo no estado físico que fiquei depois de tudo isto, ainda fui pendurado no pau de arara, passei pela cadeira do dragão, apanhei etc. Não desço a maior detalhe porque o essencial já foi colocado, mas apelo à imaginação de vossa excelência. Para que se lembre de cada dor, de cada sofrimento que já passou em sua vida e por eles avalie o que passei (CNV, 2014, p. 390).
\end{abstract}

Alguns pontos merecem destaque na carta de Carlos Eduardo, o primeiro diz respeito ao suicídio como uma única escapatória possível para o sofrimento, e como uma forma de resistir às torturas, o que vai ao encontro do caso do Frei Tito. $\mathrm{O}$ segundo ponto, que desenvolveremos melhor, faz referência à necessidade da ficção na cena testemunhal, para que a testemunha consiga se colocar no seu lugar. Assim o militante pede ao ministro que use 
a imaginação e se lembre das suas dores pessoais para que possa se colocar no lugar da vítima. Os testemunhos tornam pública a experiência aparentemente intransmissível do horror, e funcionam como uma válvula de escape para o mal que atormenta a vítima.

\begin{abstract}
embora uma fração do confronto com o Real (a morte/ a crueldade extrema, inimaginável/ a cena inconsciente posta a nu) permaneça irrepresentável e nenhuma experiência narrada seja idêntica ao vivido, os livros [...] respondem não apenas a uma necessidade urgente e vital de seus autores, como também a uma necessidade do mundo (KEHL, 2011, p.312).
\end{abstract}

Foi isso o que Bernardo Kuscinki realizou em $K$., usou o recurso da imaginação e escreveu capítulos ficcionais que representavam o que ele tentava imaginar. Ana Rosa desapareceu com o marido e sua história foi ocultada da família, que buscou notícias extraoficiais e compôs um enorme quebra cabeças a qual deu origem a obra literária objeto dessa dissertação. O trabalho sobre a memória foi de suma importância para que a história de Ana Rosa pudesse ser contada, numa tentativa do autor de deixar o passado para trás e, finalmente, elaborá-lo. Segundo Kehl, "é o trabalho da memória que permite o verdadeiro esquecimento, o desligamento das cargas libidinais fixadas na representação da cena traumática" (KEHL, 2011, p.311).

O trabalho das diversas comissões criadas no país é fundamental para que casos de violação dos direitos humanos ocorridos no e pelo Estado brasileiro venham à tona. Precisamos devolver a dignidade às vítimas, reescrever a história do período pelo viés do testemunho. Segundo KEHL(2011), escutar a voz dos antigos militantes ou de seus representantes é essencial para o amadurecimento político da sociedade brasileira.

No Brasil, os projetos de reparação de injustiças são caracterizados como meros revanchismos e logo são sufocados. Falar sobre crimes e seus responsáveis parece uma agressão à lei da anistia. Segundo KEHL (2011), não importam as vidas envolvidas; o que se leva em consideração é a imagem de povo alegre, feliz, logo, perdoador. Guardar mágoas é coisa de gente mesquinha e nós, brasileiros, somos o "último povo feliz" do planeta. Nosso compromisso com a alegria nos faz rejeitar os projetos de reparação de injustiças do passado. "Tal compromisso nos impede de levar a reparação das injustiças às últimas consequências. Temos pressa em perdoar nossos inimigos com medo de parecer ressentidos" (KEHL, 2011, 
p.326). Com isso não passamos nada a limpo e estamos em dívida com a sociedade. Não elaboramos nossos traumas, não damos a conhecer às novas gerações a violência do estado brasileiro perpetrada durante a ditadura militar. O não conhecimento desse período histórico possibilita que vejamos durante manifestações de rua no Brasil faixas reivindicando a volta dos militares ao poder. Não construímos nossa identidade. Reitero a pergunta feita por KEHL (2011), “quem somos nós brasileiros?”, e completo: Quais foram as memórias que utilizamos para construir a nossa história?

\section{Referências}

BRASIL. Comissão Nacional da Verdade. Relatório / Comissão Nacional da Verdade. Recurso eletrônico. - Brasília: CNV, 2014.

FENICHEL, Otto. Teoria psicanalítica das neuroses. São Paulo: Editora Atheneu, 2005.

JUIZ DE FORA. Comissão Municipal da Verdade. Memórias da repressão: relatório da Comissão Municipal da Verdade de Juiz de Fora. / Comissão Municipal da Verdade. Juiz de Fora: MAMM, 2015.

KEHL, Maria Rita. Comentários sobre K. de Bernardo Kuscinski. Blog Boitempo, São Paulo, 28 nov. 2011, Disponível em: http://blogdaboitempo.com.br/2011/11/28/comentariossobre-k-de-bernardo-kucinski/ Acesso em: 27 jan. 16.

. Maria Rita Kehl associa tortura a 'gozo proibido': entrevista para a Folha de S.Paulo. Blog Boitempo, São Paulo, 16 maio. 2012. Disponível em: https://blogdaboitempo.com.br/2012/05/16/maria-rita-kehl-associa-tortura-a-gozoproibido-entrevista-para-a-folha-de-s-paulo/ Acesso em: 25 ago. 16.

O ressentimento camuflado da sociedade brasileira. Novos Estudos, São Paulo, n. 71, p. 163-180, 2005.

Os crimes do Estado se repetem como farsa: artigo de Maria Rita Kehl sobre o trauma da ditadura. Blog Boitempo, São Paulo, 25 mar. 2013. Disponível em: 
http://blogdaboitempo.com.br/2013/03/25/os-crimes-do-estado-se-repetem-como-farsaartigo-de-maria-rita-kehl-sobre-o-trauma-da-ditadura/ Acesso em: 27 jan. 16.

Ressentimento. São Paulo: Casa do Psicólogo, $4^{\mathrm{a}}$ edição, 2011.

Tortura e sintoma social. In: TELES, E.; SAFATLE, V. (Org). O que resta da ditadura: a exceção brasileira. São Paulo: Boitempo, 2010. p. 123-132.

KUCINSKI, Bernardo. K. $2^{\text {a }}$ edição. São Paulo: Expressão Popular, 2012.

LAPLANCHE, Jean. Vocabulário da psicanálise/ Laplanche e Pontalis. São Paulo:Martins Fontes, 1991. 